\title{
Everglades Agricultural Area Soil Subsidence and Sustainability ${ }^{1}$
}

\author{
Jehangir H. Bhadha, Alan L. Wright, and George H. Snyder²
}

\section{Introduction}

This document describes the soils in the Everglades Agricultural Area (EAA) and their gradual change over time. The EAA is an agricultural region south of Lake Okeechobee, Florida, growing primarily sugarcane in rotation with sweet corn, winter vegetables, sod, and rice. The objective is to describe soil losses in the EAA because this region was converted from wetlands to agricultural use, and to illustrate how these changes affect the future of agricultural sustainability in the region.

The organic soils (Histosols) of the EAA formed over a period of several thousand years when organic matter production exceeded decomposition in the flooded sawgrass prairies that flourished in the area south of Lake Okeechobee. Since the onset of drainage of the EAA soils in the early 1900s for crop production, organic matter decomposition has exceeded accretion, resulting in a loss of soil and lowering of the surface elevation, a process commonly referred to as subsidence. These Histosols are underlain by hard limestone bedrock, making subsidence all the more important, because cultivation of the bedrock by physically crushing the limestone and water management would be difficult.

These Histosols formed because the land was flooded for much of the year, resulting in insufficient oxygen in the soil to maintain active populations of aerobic microorganisms that decompose organic matter. Oxygen penetration into the soil increases upon drainage, stimulating the activity of aerobic microorganisms (Ponnamperuma 1984). These microorganisms then decompose the soil organic matter at a much higher rate compared to the anaerobic microorganisms that dominate in flooded soil (Tate and Terry 1980). As such, microbial activity as affected by drainage is considered the main factor influencing subsidence. Other factors can also influence soil subsidence, including loss of buoyancy following drainage, shrinkage, compaction caused by vehicular traffic, mineral content of the soil, and soil loss by wind erosion and burning. Each of these factors has likely been partly responsible for subsidence in the EAA. Within the EAA, Aich et al. (2013) estimated the subsidence to be approximately 6.5 feet, corresponding to 5 $\times 10^{8}$ metric tons of $\mathrm{CO}_{2}$ being emitted to the atmosphere.

\section{Soil Subsidence}

Subsidence was observed as soon as the Everglades were drained in the early 1900s to remove water from soil to better support crop production. In 1924, a graduated concrete post was driven into the underlying bedrock at the UF/IFAS Everglades Research and Education Center (EREC) in Belle Glade, Florida. The soil surface was level with the top of the post, which is 9 feet in length (Figure 1). During a 43-year period from 1924 to 1967, there was

1. This document is SL 311, one of a series of the Department of Soil and Water Sciences, UF/IFAS Extension. Original publication date October 2009. Revised March 2020. Visit the EDIS website at https://edis.ifas.ufl.edu for the currently supported version of this publication.

2. Jehangir H. Bhadha, assistant professor, Department of Soil and Water Sciences, UF/IFAS Everglades Research and Education Center; Alan L. Wright, professor, Department of Soil and Water Sciences, UF/IFAS Indian River REC; and George H. Snyder, distinguished professor emeritus, Department of Soil and Water Sciences, UF/IFAS EREC; UF/IFAS Extension, Gainesville, FL 32611.

The Institute of Food and Agricultural Sciences (IFAS) is an Equal Opportunity Institution authorized to provide research, educational information and other services

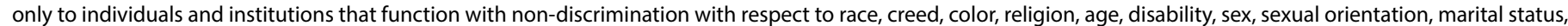

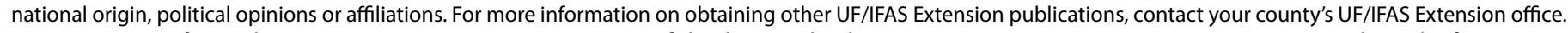
U.S. Department of Agriculture, UF/IFAS Extension Service, University of Florida, IFAS, Florida A \& M University Cooperative Extension Program, and Boards of County Commissioners Cooperating. Nick T. Place, dean for UF/IFAS Extension. 
a 48 -inch decline in soil depth at the subsidence post, resulting in a subsidence rate of 1.12 inches/year (Figure 2). As of 2009, the soil depth at the site was 37 inches. From 1968 to 2009, the elevation reduction was 23 inches, for an average subsidence rate of 0.55 inches/year. From 2010 to 2019 , the elevation reduction was 2.5 inches, resulting in an average subsidence rate of 0.25 inches/year. At this site, it is apparent that the soil subsidence rate has not remained constant through time, and in fact has decreased by $50 \%$ from $1924-1967$ to $1968-2009$, and by $55 \%$ from the period of $1968-2009$ to $2010-2019$.

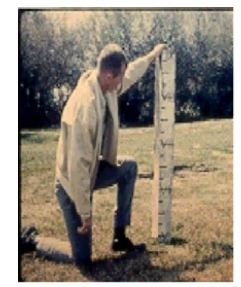

1968

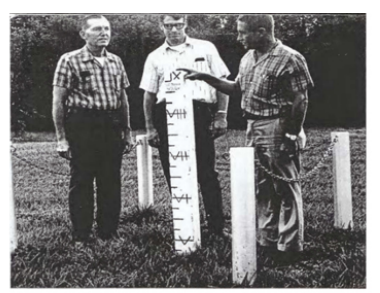

1972
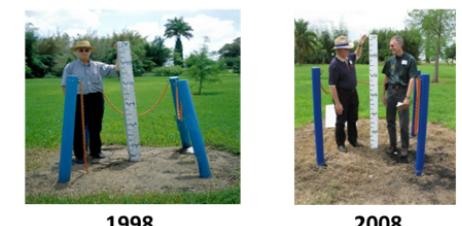

2008

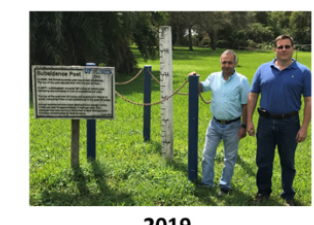

2019

Figure 1. Soil subsidence post being used to visually document the change in soil loss since 1924. Note: This post is located at the EREC, in Belle Glade, FL, and may not be typical of other areas, because it has no crop and is drained most of the year.

Credits: Alan L. Wright, George H. Snyder, and Jehangir H. Bhadha, UF/ IFAS

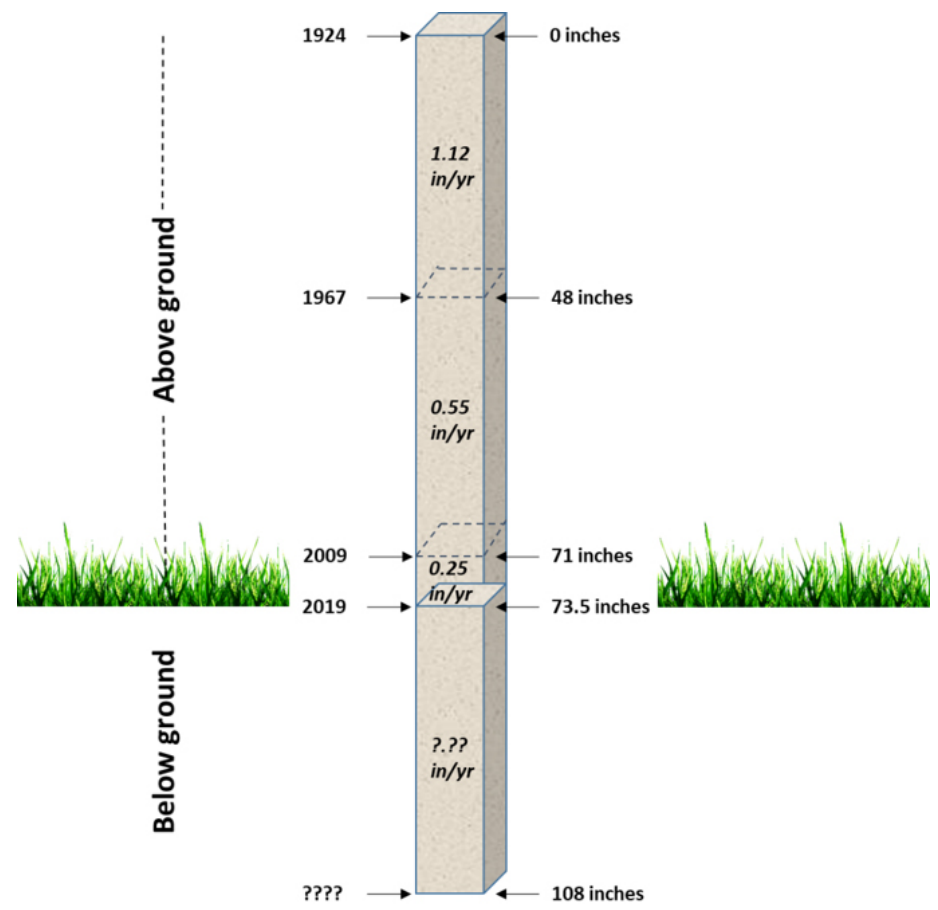

Figure 2. Changes in rate of soil subsidence since 1924.

Credits: Jehangir H. Bhadha, UF/IFAS
The rate of subsidence throughout the EAA has been investigated and documented in several other ways. The subsidence rate estimate at the EREC subsidence post coincides favorably with estimates obtained from transect lines monitored across the EAA (Shih et al. 1998). Starting in 1913, and further augmented in the 1930s, a series of transects (termed subsidence lines) were established in which the surface elevation relative to mean sea level was measured at 25-to-50-foot intervals for a distance of several thousand feet every 5 to 20 years. Two east-west elevation transects were made in 1912, and a much more detailed measurement of surface elevation was made throughout the entire Everglades in 1939-1940.

In the 1930s, a study was conducted at EREC to relate the rate of subsidence to the depth to water table (Neller 1944). Based on this study, Stephens and Johnson (1951) concluded that the subsidence rate would be one foot per decade, assuming that the water table is maintained at a depth of 18-24 inches. The resulting subsidence rate was calculated to be 1.2 inches/year, and this estimate was later substantiated by Shih et al. (1978) by monitoring the transect lines. Shih et al. (1998) measured surface elevation along the subsidence lines following a 19-year lapse in measurement and concluded that the subsidence rate during this period averaged 0.57 inches/year. This rate was significantly lower than the 1.2 inches/year calculated by Stephens and Johnson (1951), and Shih et al. (1998) speculated that maintenance of higher water tables after 1978 was one of the major reasons for the observed reduction in the subsidence rate.

It thus appears that the subsidence rate has shown a declining trend over time. Several potential mechanisms can explain this decline, including increased mineral content in soil (Figure 3), humification, and water management (maintenance of higher water tables).

One argument for a decrease in subsidence is that as these soils continue to get shallower, mineral matter composed mostly of calcium carbonate within the organic soil profile starts to increase. As the organic matter is decomposed, the mineral content, such as calcium carbonate, sand, or clay, does not change, and in fact, its proportion to the total soil increases as subsidence continues. This theory has been corroborated by the gradual increase in soil $\mathrm{pH}$, from about 5.5 when these soils were drained (Wright et al. 2018) to as high as 8.0 in regions where the soils are shallow (Bhadha et al. 2018). 


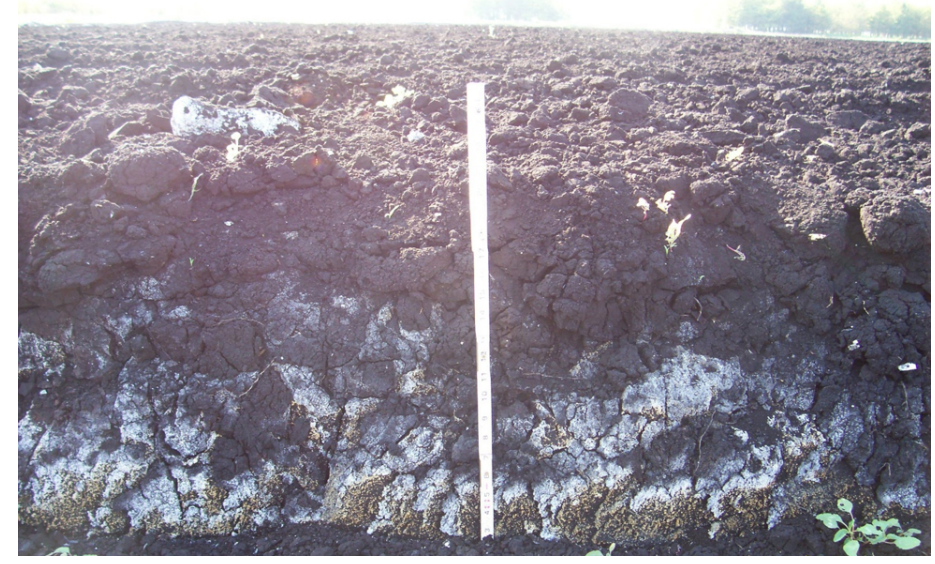

Figure 3. Presence of calcium carbonate in the form of limestone gets higher as the soils become shallow, raising the $\mathrm{pH}$.

Credits: Alan L. Wright, UF/IFAS

As Histosols decompose, the easily degradable components are lost first, but the more resistant components persist longer, leading to decreases in the subsidence rate. The organic soils should become less easily oxidized with time as they become more humified and as the organic particles become more resistant to decomposition start to accumulate (Olk et al. 1996). In addition to accumulation of mineral matter, such a theory could predict or account for a reduced subsidence rate as soils become very thin (shallow) over bedrock.

Another major factor influencing the decline in the subsidence rate through time has been improved water management. It has been well documented that the subsidence rate is closely aligned with water table depth, because organic matter decomposition is impaired by flooded conditions (Stephens and Johnson 1951; Snyder et al. 1978). Implementation of best management practices (BMPs) in the mid-1990s has led to more water storage on EAA fields, which helps to slow organic matter decomposition and decrease the subsidence rate. The rate of oxidation of organic matter under flooded anaerobic conditions is significantly slower compared to aerobic conditions.

\section{Current Trends}

During the 1930s and 1940s, vegetables were the primary crops in the EAA, and they required good water control and did not tolerate flooded or waterlogged soils. Widespread adoption of sugarcane in the early 1960s led to changes in crop and land management practices, which increased water storage in EAA fields because sugarcane is more tolerant of flooded conditions. During the summer period, more than 50,000 acres of fallow sugarcane land is available for flooded rice production (Bhadha et al. 2016). In addition to being a food crop in Florida, production of flooded rice provides several benefits to the EAA agroecosystem. By flooding fields, growers greatly reduce the negative impacts from issues related to insect pests (Cherry et al. 2015). This in turn enhances the subsequent sugarcane crop and maximizes the longevity of the soil by reducing soil loss due to oxidation. Soil insecticides for wireworm control are rarely needed, if ever, when planting sugarcane after rice (Cherry 2014). Shih et al. (1982) also observed that temperature reduction in sugarcane fields decreased the subsidence rate by $16 \%$. These two mechanisms (water and temperature) suggest that widespread cultivation of sugarcane contributed to a decrease in the rate of soil subsidence in recent years. Growers have also modified field operations in response to shallower soils by tilling less deeply and making fewer passes over the fields, which minimizes soil disturbance. Thus, growers have contributed to the reduction of the soil subsidence rate through their management practices. Continuation of BMP implementation by growers, development of crop cultivars more tolerant of flooded conditions, reduced tillage, and potential adoption of green manure crop rotations, will likely further minimize subsidence in the future and increase the longevity of these soils for agricultural use.

\section{References}

Aich, S., C. W. McVoy, T. W. Dreschel, and F. Santamaria. 2013. "Estimating Soil Subsidence and Carbon Loss in the Everglades Agricultural Area, Florida Using Geospatial Techniques." Agriculture, Ecosystems \& Environment. 171: 124-133. https://doi.org/10.1016/j.agee.2013.03.017

Bhadha, J. H., R. Khatiwada, S. Galindo, N. Xu, and J. Capasso. 2018. "Evidence of Soil Health Benefits of Flooded Rice Compared to Fallow Practice." Sustainable Agriculture Research. 7: 31-41. https://doi.org/10.5539/sar.v7n4p31

Bhadha, J. H., L. Trotta, and M. VanWeelden. 2016. Trends in Rice Production and Varieties in the Everglades Agricultural Area. SL439. Gainesville: University of Florida Institute of Food and Agricultural Sciences. https://edis.ifas. ufl.edu/ss653

Cherry, R. 2014. Wireworms in Florida Sugarcane. ENY665. Gainesville: University of Florida Institute of Food and Agricultural Sciences. https://edis.ifas.ufl.edu/sc013

Cherry, R., M. Tootoonchi, J. H. Bhadha, T. A. Lang, M. Krounos, and S. Daroub. 2015. "Effect of Flood Depth on Rice Water Weevil (Coleoptera: Curculionidae) Populations in Florida Rice Fields." Journal of Entomological Science. 50: 311-317. https://doi.org/10.18474/JES15-05.1 
Neller, J. R. 1944. “Oxidation Loss of Lowmoor Peat in Fields with Different Water Tables." Soil Science. 58: 195-204.

Olk, D. C., K. G. Cassman, E. W. Randall, P. Kinchesh, L. J. Sanger, and J. M. Anderson. 1996. "Changes in Chemical Properties of Organic Matter with Intensified Rice Cropping in Tropical Lowland Soil." European Journal of Soil Science. 47: 293-303. https://doi. org/10.1111/j.1365-2389.1996.tb01403.x

Ponnamperuma, F. N. 1984. "Effects of Flooding on Soils." In Flooding and Plant Growth, edited by T. T. Kozlowski. 10-45. New York: Academic Press Inc.

Shih, S. F., B. Glaz, and R. E. Barnes Jr. 1998. "Subsidence of Organic Soils in the Everglades Agricultural Area during the Past 19 Years." Soil Crop Soc. Fl. Proc. 57: 20-29.

Shih, S. F., G. S. Rahi, H. Y. Ozaki, and A. G. Smajstrla. 1982. "Effect of Water Table and Crops on Soil Temperature." Soil Crop Sci. Soc. Fl. Proc. 41: 47-54.

Snyder, G. H., H. W. Burdine, J. R. Crockett, G. J. Gascho, D. S. Harrison, G. Kidder, J. W. Mishoe, D. L. Meyer, F. M. Pate, and S. F. Shih. 1978. Water Table Management for Organic Soil Conservation and Crop Production in the Florida Everglades. Bull. 801. Gainesville: University of Florida Institute of Food and Agricultural Sciences. https:// ufdc.ufl.edu/UF00027622/00001/1j

Stevens, J. C., and L. Johnson. 1951. "Subsidence of Organic Soils in the Upper Everglades Region of Florida." Soil Sci. Soc. Fl. Proc. 11: 191-237.

Tate, R. L. III, and R. E. Terry. 1980. "Variation in Microbial Activity in Histosols and Its Relationship to Soil Moisture." Applied and Environmental Microbiology. 40: 313-317.

Wright, A. L., E. A. Hanlon, and R. W. Rice. 2018. Managing pH in the Everglades Agricultural Soils. SL287. Gainesville: University of Florida Institute of Food and Agricultural Sciences. http://edis.ifas.ufl.edu/ss500 